\title{
Themes in the promotion of Greenland's mineral resource potential
}

Peter R. Dawes

The production of minerals has been an important industry in Greenland. With a life-span of over 100 years the cryolite deposit at Ivittuut (Fig. 1) assured Greenland a place in world mining annals. Cryolite extraction ceased in 1987. A more recent venture, the Black Angel lead-zinc mine at Maarmorilik, focused international attention on the potential for base metals and with a production from 1973 to 1990 contributed notably to the development of Greenland's economy. With the Black Angel's closure, Greenland is left for the first time this century without an operative mine. Consequently the promotion of Greenland's mineral resources has now become a foremost political objective.

The multidisciplinary investigations already carried out have documented a potential for economically viable deposits. Occurrences of almost all major metals have been discovered as well as a range of industrial minerals. Seen in relation to neighbouring landmasses, North America and Europe, where similar geological terraines occur, it must be concluded that Greenland has yet to realise its mineral resource potential. Apart from the Geological Survey of Greenland's (GGU) commitment towards applied geology and resource characterisation as steps facilitating the search for new economic resources (see Dawes, this report), specific promotion programmes with oral and visual presentations are an integral part of GGU's work.

The main venues and intentions of the 1992 international promotion campaign were described in last year's Report of Activities (Dawes et al., 1993). This paper describes the main geological themes that were focused on in the travelling demonstration, that in its second year (1993) concentrated on North America with visits to Vancouver in January (British Columbia \& Yukon Chamber of Mines, 10th Annual Cordilleran Geology and Exploration Roundup), Toronto in March (Prospectors and Developers Association of Canada, Annual Convention and Exhibition; Fig. 2), Denver in April (Annual Conference, Society of Exploration Geophysicists), finishing the year at Spokane in December (99th Annual Convention and Trade Show, Northwest Mining Association).

\section{General geology and mineral potential}

Designed as a basic introduction to exploration and mining audiences, emphasis in the demonstrations was placed on Greenland's complete geological column with rocks ranging from earliest Precambrian to Cenozoic in age, and on the main geological provinces and their distinctive metalliferous potential. Geographical and logistic aspects of mineral exploration were also included. A summary of the geological part of the presentation was published in last year's Report of Activities (Schønwandt \& Dawes, 1993).

\section{Specific mineral deposits}

Past enterprises, such as the Ivittuut cryolite open-pit, and the Black Angel and Blyklippen lead-zinc mines (Fig. 1) were focused on as examples of Greenland's mining history and of the feasibility of mineral exploitation in Greenland's arctic conditions. These examples and specific sub-economic deposits with proven ore reserves were illustrated in map and photograph displays and by rock specimens. The sub-economic deposits featured included:

- Malmbjerg molybdenum with $150 \times 10^{6}$ t. grading $0.23 \% \mathrm{MoS}_{2}$.

- Isua iron ore with $1900 \times 10^{6}$ t. grading $32.9 \% \mathrm{Fe}$.

- Skaergaard precious metals with $43 \times 10^{6}$ t. grading 2.4 ppm Au.

- Gardar alkaline intrusions with $30 \times 10^{6}$ t. grading $0.25 \% \mathrm{Nb}$ and $56 \times 10^{6}$ t. grading $365 \mathrm{ppm} \mathrm{U}$.

- Fiskenæsset chromite with $100 \times 10^{6}$ t. grading $14 \%$ $\mathrm{Cr}_{2} \mathrm{O}_{3}$.

\section{Greenland geodata}

Description of the nature, scope and availability of geodata from Greenland, formed a major promotion theme. Exhibits showed the range of GGU publications and other relevant Greenland literature with special emphasis on available map coverage (both systematic map sheets and coverage of regions with special economic interest) as a basic prerequisite for mineral resource assessment. This 

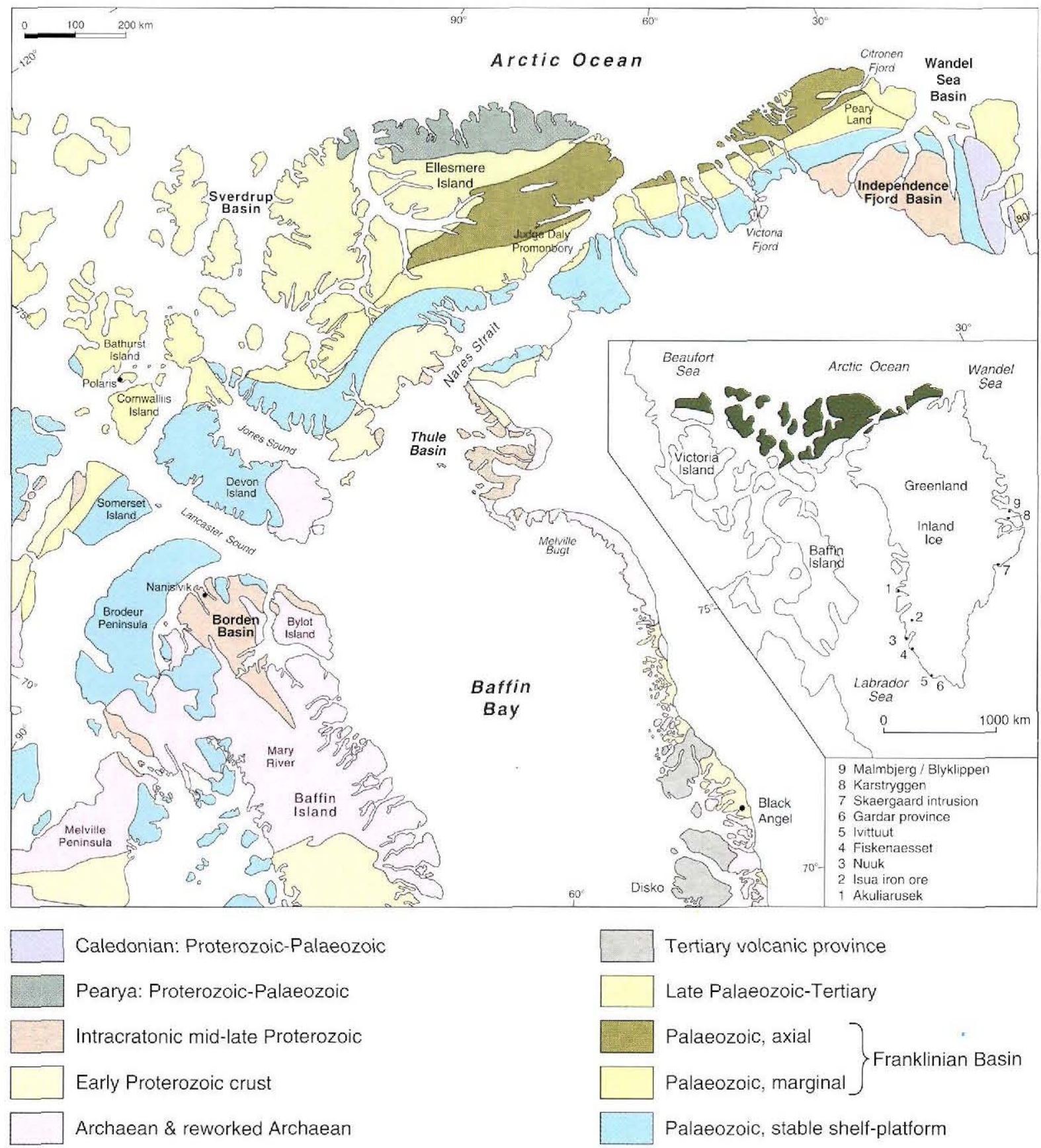

Fig. 1. Geological and location map of northern Greenland and adjacent Canada showing the main geological provinces and (inset, shaded) the regional extent of the Franklinian Basin. In Greenland the Navarana Fjord escarpment broadly corresponds to the southern boundary of the axial region of the basin. Canadian geology is mainly from Trettin (1991); Greenland geology is from published GGU sources.

publication display was supplemented by information on unpublished archive material, digital data and advisory services offered by the Survey. Emphasis was placed on new approaches to data processing and presentation, such as the Thematic Map Series and the Greenland Mineralisation Data Bank (GREENMIN. Lind et al., this report), and on the range and availability of geological, geophysical and geochemical digital data sets. A summary of the 
scope of the geodata is presented in this Report of Activities (Dawes, this report).

\section{Kimberlites}

Triggered by the Lac de Gras diamondiferous kimberlite discovery in the Canadian Northwest Territories (Schiller, 1992), North America is experiencing diamond fever. This. has caused renewed interest in the Archaean block of West Greenland where kimberlites, lamproites and related rocks have been known for decades and where a few microdiamonds have been recovered (Larsen, 1991). Display information showed that the Greenland kimberlites, occurring as dykes, sills and local diatremes, constitute a major province stretching north-south for over $1300 \mathrm{~km}$ $\left(60^{\circ}-72^{\circ} \mathrm{N}\right)$, and that the rocks originated in the diamond stability field (Larsen \& Rønsbo, 1993). Attention was also directed to northern Greenland as a prospective kimberlite target (see below).

\section{Greenland - Canada relations}

Canada, Greenland's closest neighbour, has a wellestablished mineral industry. Geologically, Greenland is a part of North America, and portions of the same geological provinces face each other across the Labrador SeaBaffin Bay - Nares Strait seaway that now separates the two landmasses. In Canada, some of these provinces support active mining; in Greenland economic mineral exploration is in its infancy.

This message was illustrated by focusing in on northern Greenland and adjacent parts of the Arctic Islands of Cana$\mathrm{da}$, the latter region supporting the world's most northerly metal mines, Polaris and Nanisivik (Fig. 1). The geological unity of Greenland and Canada in this region is obvious and the two mined deposits are hosted in provinces that have direct counterparts in Greenland. The close geological ties between Canada and Greenland at these latitudes is best illustrated by three provinces: the Precambrian shield, the mid- to late Proterozoic intracratonic basins and, overlying them to the north, the Palaeozoic Franklinian Basin. Of these provinces the Franklinian Basin, showing on-strike continuity across Nares Strait, best illustrates the geological homogeneity of the region. This basin stretches as a continuous tract for over $2500 \mathrm{~km}$ from the Wandel Sea across northern Greenland and the Arctic Islands of Canada to the Beaufort Sea (Fig. 1). Sedimentary basin analysis is at an advanced stage revealing a comparative evolution of the Greenlandic and Canadian segments of the basin. Thus, basin configuration and development, characterised by the progressive shift south of the axial region throughout the Lower Palaeozoic, are now well documented from both sides of Nares Strait (Trettin, 1991).
Geological comparisons of four different ages from the Baffin Bay - Nares Strait region were highlighted during the promotion venues.

\section{Archaean - early Proterozoic}

Based on lithology and isotopic dating, correlation of the major blocks of high-grade Archaean and early Proterozoic rocks in the northern Baffin Bay region can be made with confidence (Dawes et al., 1988; Frisch \& Hunt, 1988; Jackson \& Hegner, 1991; Fig. 1). One comparison with economic implications is between the Archaean - Aphebian terraines of northern Baffin Island and North-West Greenland where supracrustal rocks with iron-rich sequences are prominent in some areas (Gross, 1966; Jackson, 1966; Dawes \& Frisch, 1981). North-West Greenland is the possible eastern extension of the $1700 \mathrm{~km}$ long Committee Fold Belt (Jackson, in press). Thus the banded iron formation occurrences bordering Melville Bugt, that are poorly known but traceable for $350 \mathrm{~km}$, are likely correlatives of the iron ore deposits of the Mary River Group of northern Baffin Island and adjacent Melville Peninsula. The Canadian occurrences of Algoma-type are among the highest grade iron deposits in the world and show anomalous gold values (Wilson \& Underhill, 1971; Jackson, in press). The Mary River banded iron occurrences are characterised by layers of pure hematite and magnetite; banded iron-rich sequences with layers of pure magnetite are known from Melville Bugt.

\section{Mid- to late Proterozoic}

A number of mid- to late Proterozoic basins occur on the northern rim of the North American craton (Young, 1979). These basins, characterised by thick sandstone units and volcanic rocks at lower levels succeeded by carbonate/shale-dominated sequences, have metallic potential, notably for sedimentary and volcanic hosted copper and for carbonate-hosted lead-zinc. In Canada mineral deposits have been discovered in several of these basins and mining is taking place. The most significant (and closest to Greenland) is the Nanisivik lead-zinc-silver deposit in the Borden Basin of northern Baffin Island and Bylot Island that has been mined since 1976 (Olson, 1984; Jackson \& Iannelli, 1989). The coeval, rift-related Thule Basin of North-West Greenland and south-east Ellesmere Island shows many similarities in structural setting and stratigraphy to the Borden Basin and it has a comparable carbonate sequence to the ore-bearing Uluksan Group. Farther west, the Amundsen Basin on Victoria Island shows a range of copper mineralisations, both sedimentand volcanic-hosted occurrences. For example, the Shaler Group shows copper sulphides disseminated in quartz arenites (Rainbird et al., 1992) while the Neohelikian basalts of the Natkusiak Formation show a variety of native 


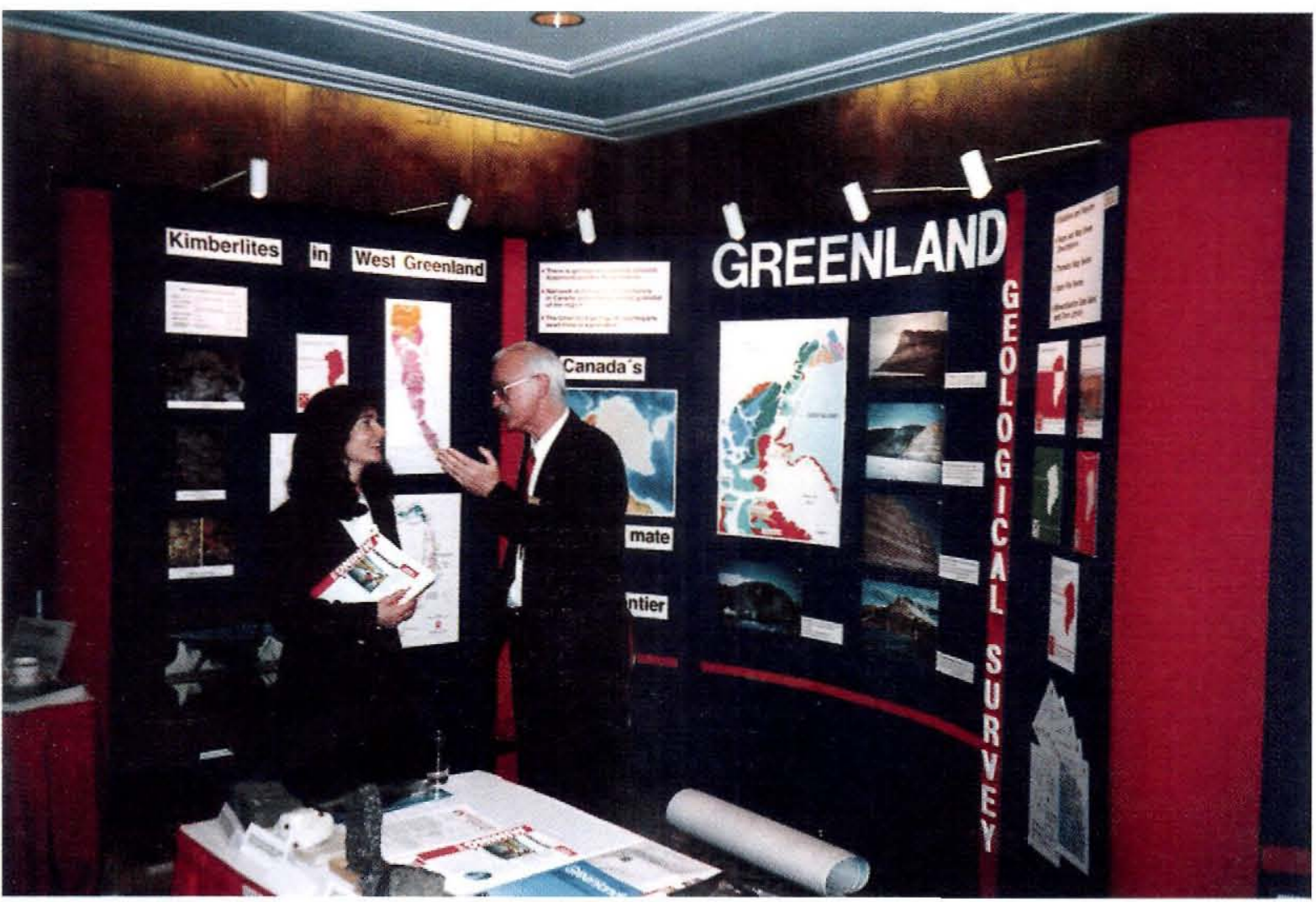

Fig. 2. View of GGU's promotion booth at Toronto at the Annual Convention and Exhibition of the Prospectors and Developers Association of Canada, March 1993.

copper and sulphide showings (Jefferson et al., 1985; Gibbins, 1991). Interesting comparisons can be made with showings in Greenland, viz. the disseminated malachite in quartz arenites of the Thule Basin and the native copper occurrences in the Zig-Zag Dal Basalt Formation of the Independence Fjord basin of eastern North Greenland that are of similar age and geological setting.

\section{Palaeozoic}

The Palaeozoic Franklinian Basin, with its prominent and intricate facies changes between platform/shelf and deep water trough shows good potential for carbonatehosted lead-zinc in the platform/shelf facies and for sedimentary exhalative deposits in basinal facies. In Canada notable sulphide deposits of both these types have been located: in Greenland promising showings have been found (see later). The most notable carbonate-hosted occurrences in Canada are the high-grade, Mississippi Valleytype lead-zine deposits of the Cornwallis district, with the operational underground Polaris mine (underway since 1982), while for shale-hosted deposits, the most spectacular discovery is the galena-sphalerite occurrence in the Hazen Formation at Judge Daly Promontory (Gibbins,
1991) - just $25 \mathrm{~km}$ from the Greenland coast (Fig. 1). This formation is a direct equivalent to the Amundsen Land Group of Greenland. Judge Daly Promontory is the site of the facies boundary between shelf carbonates and deep-water clastics that strikes across northern Greenland as the Navarana Fjord escarpment. Zinc-barium mineralisation and stream-sediment zinc-barium anomalies are associated with this and other east-west trending features (Steenfelt, 1991).

As a fitting aftermath (that could be reported on at the last promotion meeting of the year at Spokane), these promising showings and anomalies in Greenland have been realised by the discovery in May 1993 of a major body of bedded zinc, lead and iron sulphides in a geological setting comparable to the Judge Daly Promontory occurrence, i.e. in starved slope facies adjacent to the facies boundary between carbonates and deep-water clastics. This occurrence of massive sulphides at Citronen Fjord in Peary Land hosted by black shales is exposed over a strike length of more than a kilometre (Schønwandt, this report). The discovering company. Platinova A/S, completed during the summer the first diamond drilling programme through the mineralisation intersecting beds 
of zinc-bearing massive sulphides at several stratigraphic levels. This programme has proved the widespread distribution of base metal mineralisation in a geological setting that not only corresponds to Canadian counterparts but one that hosts the world's largest zinc deposits.

\section{Cretaceous}

Kimberlite pipes of Cretaceous age pierce the Silurian carbonate platform strata on Somerset Island and a few microdiamonds have been recovered for example in the Batty kimberlites (Mitchell 1976; Gibbins 1991). The region is being intensely explored and kimberlite bodies have also been discovered on Bathurst Island and Brodeur Peninsula (Fig. 1). The corresponding platform strata in Greenland (that at least in part overlie Archaean crust) thus designate a prospective kimberlite exploration target.

\section{Greenland: underexplored/good geodatabase}

Sound regional geoscientific knowledge is a prerequisite for a meaningful evaluation of mineral resource potential. This must be said to exist for Greenland; basic geological information is available for all regions in the form of maps, reports and rock samples. Compared, however, to many other countries Greenland is unexplored from a mineral resource point of view.

The combination of being underexplored but having a good database is an important message. In promotion terms Greenland has been courted as the northern hemisphere's last exploration frontier (Schønwandt \& Dawes, 1992). That this is meaningful is substantiated by the abovementioned discovery in 1993 of the major, surface-outcropping, massive lead-zinc sulphide mineralisation in the Franklinian Basin in Peary Land. This is from a region that has recently been the subject of systematic mapping, basin and lithostratigraphic analysis, and regional geochemistry studies (Higgins et al., 1991; Steenfelt, 1991; Henriksen, 1992). This promising find prompted the comment from industry that it is the underexplored/good geodata combination that still makes discoveries of the Peary Land type possible and stamps Greenland as "an exploration opportunity unique in the developed world" (R. Gannicott, in MINEX, 1993).

\section{References}

Dawes, P. R. \& Frisch, T. 1981: Geological reconnaissance of the Greenland shield in Melville Bugt, North-West Greenland. Rapp. Grønlands geol. Unders. 105, 18-26.

Dawes, P. R., Larsen, O. \& Kalsbeek, F. 1988: Archaean and Proterozoic crust in North-West Greenland: evidence from $\mathrm{Rb}-\mathrm{Sr}$ whole-rock age determinations. Can. J. Earth Sci. 25, 13651373.
Dawes, P. R., Schønwandt, H. K. \& Thomassen, B. 1993: Greenland mineral resource information to industry: increased scope in 1992. Rapp. Grønlands geol. Unders. 159, 18-21.

Frisch, T. \& Hunt, P. A. 1988: U-Pb zircon and monazite ages from the Precambrian Shield of Ellesmere and Devon islands, Arctic Archipelago. Pap. geol. Surv. Can. 88-2, 117-125.

Gibbins, W. A. 1991 [issued 1992]: Economic mineral resources, Arctic Islands. In Trettin, H. P. (ed.) Geology of the Innuitian orogen and arctic platform of Canada and Greenland, 533-539. Geology of Canada 3 (also Géologie du Canada 3 and The Geology of North America E). Ottawa: Geological Survey of Canada.

Gross, C. A. 1966: The origin of high-grade iron deposits on Baffin Island, N.W.T. Can. Mining J. 87, 111-114.

Henriksen, N. 1992: Geological map of Greenland 1:500 000. Descriptive text. Nyeboe Land, Sheet 7. Peary Land, Sheet 8. 40 pp. Copenhagen: Grønlands Geologiske Unders $\varnothing$ gelse.

Higgins, A. K., Ineson, J. R., Peel, J. S., Surlyk, F. \& Sønderholm, M. 1991: Lower Palaeozoic Franklinian basin of North Greenland. In Peel, J. S. \& Sønderholm, M. (ed.) Sedimentary Basins of North Greenland. Bull. Grønlands geol. Unders. 160 , 71-139.

Jackson, G. D. 1966: Geology and mineral possibilities of the Mary River region, northern Baffin Island. Can. Mining J. 87, 57-61.

Jackson, G. D. in press: Geology of the Clyde-Cockburn Land map area, north-central Baffin Island, District of Franklin. Mem. geol. Surv. Can. 440.

Jackson, G. D. \& Hegner, E. 1991: Evolution of late Archaean to early Proterozoic crust based on Nd isotopic data for Baffin Island and northern Quebec and Ladrador. Geol. Assoc. Can. \& Min. Assoc. Can., Prog. abstr. 16, 25 only.

Jackson, G. D. \& Iannelli, T. R. 1989: Neohelikian reef complexes, Borden Rift Basin, northwestern Baffin Island. In Geldsetzer, H. H. J., James, N. P. \& Tebbutt, G. E. (ed.) Reefs, Canada and adjacent area. Mem. Can. Soc. Petrol. Geol. 13, 55-63.

Jefferson, C. W., Nelson, W. E., Kirkham, R. V., Reedman, J. H. \& Scoates, R. F. J. 1985: Geology and copper occurrences of the Natkusiak basalts, Victoria Island, District of Franklin. Pap. geol. Surv. Can. 85-1A, 203-214.

Larsen, L. M. 1991: Occurrences of kimberlite, lamproite and ultramafic lamprophyre in Greenland. Open File Ser. Grønlands geol. Unders. 91/2, $36 \mathrm{pp}$.

Larsen, L. M. \& Rønsbo, J. 1993: Conditions of origin of kimberlites in West Greenland: new evidence from the Sarfartoq and Sukkertoppen regions. Rapp. Grønlands geol. Unders. 159, 115-120.

Lind, M., Tukiainen, T. \& Thomassen, B. 1994: GREENMIN: Database system for the registration of Greenland mineral occurrences (this report).

Mitchell, R. H. 1976: Kimberlites of Somerset Island, District of Franklin. Pap. geol. Surv. Can. 76-1A, 501-502.

MINEX, 1993: Major discovery of massive sulphides: Platinova rewarded for perseverance. Greenland MINEX News 3, 9-10.

Olson, R. A. 1984: Genesis of paleokarst and strata-bound zinclead sulphide deposits in a Proterozoic dolostone, northern Baffin Island, Canada. Econ. Geol. 79, 1059-1103.

Rainbird, R. H., Darch, W., Jefferson, C. W., Lustwerk, R., Rees, M., Telmer, K. \& Jones, T. A. 1992: Preliminary stratigraphy and sedimentology of the Glenelg Formation, lower Shaler 
Group and correlatives in the Amundsen Basin, Northwest Territories: relevance to sediment-hosted copper. Pap. geol. Surv. Can. 92-1C, 111-119.

Schiller, E. A. 1992: Diamonds in Arctic Canada. Mining Mag. 42, 379-382.

Schønwandt, H. K. \& Dawes, P. R. 1992: The exploration potential of Greenland. Prospectors \& Developers Assoc. Can., International Convention and Trade Show 1992, Open Forum Session, $6 \mathrm{pp}$.

Schønwandt, H. K. \& Dawes, P. R. 1993: An overview of Greenland's mineral exploration potential. Rapp. Gronlands geol. Unders. 159, 10-16.

Steenfelt, A. 1991 [issued 1992]: Economic mineral resources, North Greenland. In Trettin, H. P. (ed.) Geology of the Innuitian orogen and arctic platform of Canada and Greenland, 539541. Geology of Canada 3 (also Géologie du Canada 3 and
The Geology of North America E). Ottawa: Geological Survey of Canada.

Trettin, H.P. 1991 [issued 1992] (ed.): Geology of the Innuitian orogen and arctic platform of Canada and Greenland. $569 \mathrm{pp}$, 9 maps. Geology of Canada 3 (also Géologie du Canada 3 and The Geology of North America E). Ottawa: Geological Survey of Canada.

Wilson, I. D. H. \& Underhill, D. H. 1971: The discovery and geology of major new iron deposits on Melville Peninsula, Eastern Arctic. Can. Mining J. 92, 40-48.

Young, G. M. 1979: Correlation of middle and upper Proterozoic strata of the northern rim of the North Atlantic craton. Trans. Roy. Soc. Edin. 70, 323-336.

P. R. D., Geological Survey of Greenland, Copenhagen 